\title{
Inge Lehmann's work materials and seismological epistolary archive
}

\author{
Erik Hjortenberg \\ National Survey and Cadastre, Denmark
}

\begin{abstract}
The Inge Lehmann archive contains thousands of seismological work documents from Inge Lehmann's private home. For a long time the author thought that the main concern was to keep the documents for posterity. There is now a renewed interest in Inge Lehmann, and some documents were presented in a poster at ESC Potsdam 2004, and the collection of documents were scanned and catalogued 2005-2006 at Storia Geofisica Ambiente in Bologna. Inge Lehmann (1888-1993) is famous for her discovery in 1936 of the earth's inner core and for work on the upper mantle. A short biography is given. After her retirement in 1953 she worked at home in Denmark, and abroad in USA and in Canada. She took part in the creation of the European Seismological Commission in 1951, and in the creation of the International Seismological Centre in 1964. Inge Lehmann received many awards. Some letters from her early correspondence with Harold Jeffreys are discussed, they show how the inner core was discussed already in 1932. A few of the author's reminiscences of Inge Lehmann are given.
\end{abstract}

Key words seismology - biography - core - manteldocuments

\section{Introduction}

Inge Lehmann (1888-1993) (fig. 1) is the Danish seismologist who discovered the earth's inner core (Lehmann, 1936). In atomic physics an equivalent act would warrant a Nobel prize (Bolt, 1987, Brush, 1985). She retired from the Danish Geodetic Institute in 1953, but continued her scientific work in Denmark, USA and Canada, and her last publication was «Seismology in the days of old» (Lehmann, 1987). In addition to her significant contribution to our understanding of the earth, she was famous for the view that seismograms from a group of stations should be read by the same person in or-

Mailing address: Dr. Erik Hjortenberg, Bakkefaldet 10, DK-2840 Holte, Denmark; e-mail: erik.hjortenberg@tdcadsl.dk der to ensure that the same phase is identified from station to station. Bolt (1997) wrote:

«Inge Lehmann had an enormous fund of knowledge and experience about seismology from its early days in this century; in retrospect, it is a great shame that more effort was not made to persuade her to write up her reminiscences in more detail.».

I was a friend and colleague of Inge Lehmann for many years, I helped her in writing her last paper in 1987, when she was 99 years old, and it is a translation of a paper she had given previously at the Danish Geophysical Society. At some point in time our collaboration afforded me to discuss her important collection of seismological publications, correspondence and other documents. When Inge Lehmann said that she wanted her epistolary archive destroyed after her death, I remarked to her that I had seen an extremely interesting book (Hansen, 1962; 1964) about Carsten Niebuhr, who went on an expedition to the Middle East 1761-1767. I said that the book could not have been written without the availability of the epistolary archive at Rigsarkivet, the Danish 


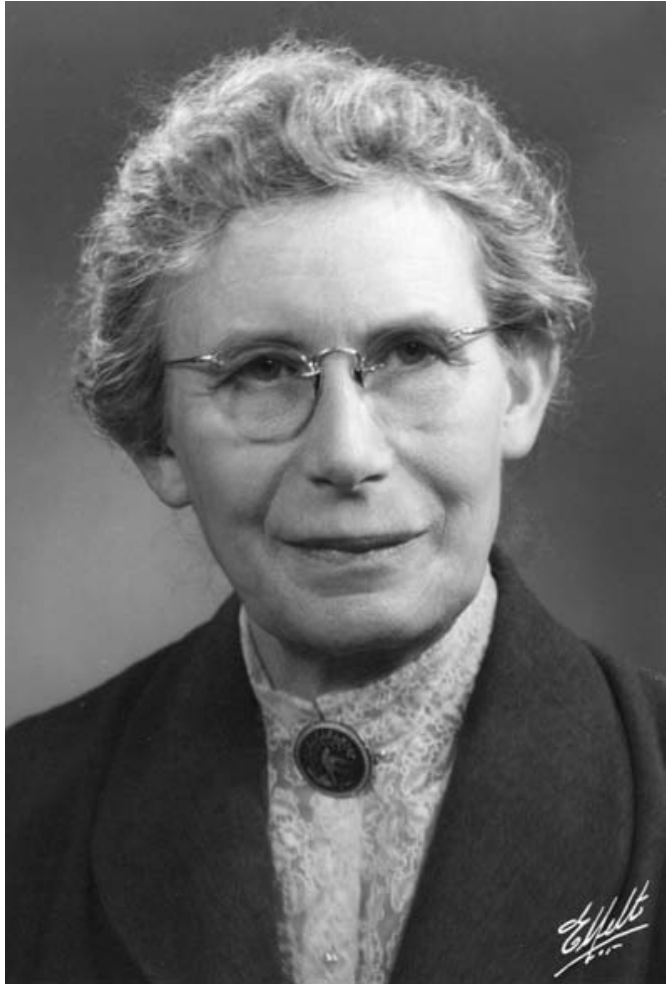

Fig. 1. Inge Lehmann (1888-1993).

National Archive. Later she left me in her will some seismological correspondence, books, card files, seismograms and other work materials, which now make up the Inge Lehmann archive. I hope that the archive will prove to be useful to the seismologists and historians.

For a long time I wondered how great was the interest in the Inge Lehmann archive, and I waited for the documents to become historical, with no clear feeling when that happens. In 2003, to my surprise (being retired) I was invited to present a paper at the «Second Seminar on the Scientific Correspondence in Earth Sciences: Historic Value and Scientific Relevance». The seminar was held on September 29, 2003 on the island of Ischia, and it was part of the celebrations to commemorate the 75th anniversary of the death of Giulio Grablovits, the seismologist who took care of the Casamicciola seismic observatory on the island of Ischia. The seminar was organized by SGA (Storia Geofisica Ambiente, Bologna) and ING (Istituto Nazionale di Geofisica e Volcanologia, Naples). As preparation for my seminar talk I started cataloguing the archive after discussing procedures for that with Finn Åserud at the Niels Bohr archive. The procedure I used was to put numbered wrappers around Inge Lehmann's original wrappers or groups of pages in the stack. The purpose was to make documents easier to find and put back where they were before. In some cases the information of the placement of a document is necessary to interpret the document. The talk was more about the life of Inge Lehmann than about the archive, and so is this paper. Some examples of archive material will be discussed in Section 6 , and in last paragraphs of Section 3.

There was an interest shown for Inge Lehmann when Louise Palmer was arranging an exhibition «Great Women, Great Science» exploring the history of women in science, including Inge Lehmann, at Bruce Museum of Arts and Science in Greenwich, Connecticut from 2004-2005, Bjarne Kousholt, who has written books on Tycho Brahe, Ole Rømer, Hans Christian Ørsted and Agner Krarup Erlang, at high school level, has also written a book on Inge Lehmann (Kousholt, 2004). Kristian Hvidtfelt Nielsen helped me in transferring Inge Lehmann's doctoral gown from the doctor of science reward ceremony 1964 at University of Colombia in the city of New York. It was transferred so that it is now owned by Kvindemuseet (=womens museum) in Århus.

\section{Short biography of Inge Lehmann}

Inge Lehmann was born in Copenhagen, Denmark on May 13, 1888 and she died on February 21, 1993, also in Copenhagen, at 104 years of age. An overview of some of her closest family is given in table I. Her father was Alfred Lehmann, professor in Psychology at University of Copenhagen; after working in Wilhelm Wundt's psychological laboratory at Leipzig 1885-1886 he introduced to Denmark the study of experimental psychology, and like Inge Lehmann he enjoyed activities such as 
Table I. Some of Inge Lehmann's closest family.

\begin{tabular}{|c|c|c|c|}
\hline Family member name & Title etc. & Relation to Inge Lehmann & Year(s) \\
\hline Hans Jakob Tørsleff & & Grandfather, mother's father & \\
\hline Ida Sophie Tørsleff & & Mother & $1866-1935$ \\
\hline Signe Andrea Tørsleff & $\begin{array}{l}\text { Principal, Haderslev Lower } \\
\text { Secondary School }\end{array}$ & Aunt, Mother's sister. & $1879-1975$ \\
\hline $\begin{array}{l}\text { Lis Groes } \\
\text { (Anne Lisbeth G.) }\end{array}$ & $\begin{array}{l}\text { Danish Trade Minister 1953-1957 } \\
\text { Member of Parlament 1960-1971 }\end{array}$ & $\begin{array}{l}\text { Cousin, Signe } \\
\text { Andrea Tørsleff's daughter }\end{array}$ & 1910-1974 \\
\hline Ebbe Groes & $\begin{array}{l}\text { General Manager, Fællesforeningen } \\
\text { for Danmarks Brugsforeninger (Coop) }\end{array}$ & $\begin{array}{l}\text { Husband to Lis Groes } \\
\text { Father to Nils Groes }\end{array}$ & $1910-2000$ \\
\hline Nils Groes & $\begin{array}{l}\text { Executive Director, AKF, Institute } \\
\text { of Local Government Studies } \\
\text { Denmark }\end{array}$ & Son of Lis and Ebbe Groes & 1938 \\
\hline Harriet Hoffmann & Actress & Sister & \\
\hline $\begin{array}{l}\text { Orla Lehmann } \\
\text { (Peter Martin Orla L.) }\end{array}$ & $\begin{array}{l}\text { Politician and instrumental } \\
\text { in the first Danish } \\
\text { democratic casting }\end{array}$ & $\begin{array}{l}\text { Father's uncle, brother to } \\
\text { Wilhelm Otto Waldemar } \\
\text { Lehmann }\end{array}$ & $1810-1870$ \\
\hline $\begin{array}{l}\text { Wilhelm Otto } \\
\text { Waldemar Lehmann }\end{array}$ & $\begin{array}{l}\text { Officer, Engineer, layed telegraph } \\
\text { cable between Denmark and Sweden }\end{array}$ & $\begin{array}{l}\text { Father's father, brother to } \\
\text { Orla Lehmann }\end{array}$ & $1817-1894$ \\
\hline $\begin{array}{l}\text { Alfred Lehmann } \\
\text { (Alfred Georg } \\
\text { Ludvig L.) }\end{array}$ & $\begin{array}{l}\text { Professor of experimental } \\
\text { psychology at University } \\
\text { of Copenhagen }\end{array}$ & Father & $1858-1921$ \\
\hline Julius Lehmann & $\begin{array}{l}\text { Instructor at the Royal Danish } \\
\text { Opera, Copenhagen }\end{array}$ & Uncle (father's brother) & $1861-1931$ \\
\hline Karl Lehmann & Chief Surgeon & $\begin{array}{l}\text { Cousin } \\
\text { (Julius Lehmann's son) }\end{array}$ & $1897-1979$ \\
\hline Tyge Lehmann & $\begin{array}{l}\text { Ambassador, expert in } \\
\text { InternationalLaw, Director, } \\
\text { Human Rights Unit Royal Danish } \\
\text { Ministry of Foreign Affairs }\end{array}$ & Son of Karl Lehmann & 1941 \\
\hline
\end{tabular}

hiking in the mountains. Her mother was Ida Sophie Tørsleff, who had one more daughter, Harriet Hofmann. Her mother's sister was Signe Andrea Tørsleff, mother of Lis Groes (Anne Lisbeth Groes, the Danish trade minister 19531957). One of the sons of Lis Groes is Nils Groes, who was executor under Inge Lehmann's will in 1993. He takes care of her family correspondence while I take care of her seismological correspondance. Alfred Lehmann had a brother, Julius Lehmann, who had a son Karl Lehmann. Tyge Lehmann, Karl Lehmann's son, wrote in the Danish newspaper Politiken on March 1, 1993, that to the very end of Inge Lehmann's 
life she took an active interest in what he could tell her about the International Court case between Denmark and Norway over the maritime boundary in the Arctic Ocean between Greenland and Jan Mayen. Inge Lehmann had herself been to Jan Mayen in 1927 to explore the possibilities for establishing a Danish seismological station there. However she had found the ground on the volcanic island too loose for the delicate instruments. Instead she placed the station in Illorqortormiit (Scoresbysund), Northeast Greenland.

Her education took place in Copenhagen (1894-1906) in a private, coeducational school run by Hanna Adler, an aunt of Niels Bohr. It was an institution where boys and girls studied the same subjects, and where all learned needlepoint as well as woodwork and soccer. The school was the first coeducational school in Denmark. The book about Hanna Adler (Adlersamfundet, 1959) describes how she studied coeducational schools on a visit to USA in 1892 , and then started her own school in 1893. The book also describes how in 1943 former schoolchildren of hers, including Inge Lehmann, helped Hanna Adler to be one of the very few members of the Danish Jewish community who obtained official permission to live in Germanoccupied Copenhagen, if not the only one, provided she did not go to Sweden.

Inge Lehmann studied mathematics at the University of Copenhagen (1907-1910) and continued 1910-1911 at Cambridge, England (Newnham College). She became an assistant in an actuary's office (1912-1918 at an insurance company of the name «Danmark»). She graduated with a cand. mag. degree (candidatus magisterii) from the University of Copenhagen in 1920. She studied mathematics at University of Hamburg (professor Blaschke) in the autumn of 1922. During 1923-1926 she worked as an assistant to J. Steffensen, professor of actuarial science. In 1928 she graduated with a mag. scient. degree (magister scientiarum) from the University of Copenhagen.

In 1925 Inge Lehmann became an assistant to Niels Erik Nørlund (Bang, 1988), the director of Gradmaalingen, an institution in charge of research in fundamental geodesy in Denmark. She helped Nørlund in establishing the seismological stations Scoresbysund and Ivigtut in Greenland and took an active role in the mounting of the seismographs at the seismological station of Copenhagen.

She studied seismology in the summer of 1927 at Hamburg under E. Tams, at Darmstadt under B. Gutenberg, at Strasbourg under E. Rothé, at De Bilt under J. van Dijk and at Uccle under E. Somville. Gutenberg (Schweitzer, 2003b) was important, since he had determined the depth to the earth's core (Gutenberg, 1914), and he gave her much of his time during the one-month stay.

In 1928 Lehmann was appointed statsgeodaet (state geodesist) and made chief of the Seismological Department of the newly formed Danish Geodetic Institute under the directorship of Niels Erik Nørlund. In this position, until her retirement in 1953, she supervised the seismological stations in Greenland and Copenhagen, she worked out the bulletins of the stations, did scientific work and published many papers. A Danish children's book about Inge Lehmann (Jensen and Pedersen, 1996) describes an earthquake that Copenhagen found frightening, but Inge Lehmann thought was wonderful. In her position as state geodesist she could travel around and collect information on how the earthquake was felt. The earthquake occurred on October 31, 1930, 23 hours Greenwich Mean Time (used by seismologists), equivalent to 1 November Middle European Mean Time (used by Danish newspapers). It was described by Lehmann in 1948 (1948a, p. 11-14). An annotated list of Danish earthquakes since year 1073 is given by Lehmann (1956); update of it is given by Gregersen et al. (1998).

Lehmann attended most of the 4-yearly meetings of the International Union of Geodesy and Geophysics (IUGG), starting with the 1927 meeting in Prague, where time curves were discussed, a subject in which she was interested the rest of her life. She attended many other meetings also, for instance the study week November 19-25, 1951 at the Vatican for the problems of microseisms. Her paper there (Lehmann, 1952) demonstrated the relationship between microseismic storms (as experienced in Greenland) and cyclones. Lehmann also attended some of 
the meetings organized by Keilis-Borok and Leon Knopoff, named «Geophysical Theory and Computers» (now Mathematical Geophysics). Inge Lehmann and Harold Jeffreys attended such meetings in Cambridge, 1966, organised locally by E.R. Lapwood, and in Copenhagen, 1969, organised locally by Jørgen Hjelme (1928-2006).

Inge Lehmann was the first president of the European Seismological Federation, a federation that was replaced by the European Seismological Commission in 1951. Lehmann (1971) explains how the idea of a European Seismological Society came about at a small meeting in Strasburg 1947, and how at a meeting in Verona 1950, organized by Medi and Caloi, the European Seismological Federation was formed with Inge Lehmann as its president. However the officers of IUGG decided that if European seismologists were to have special meetings this would have to be arranged by the International Seismological Association or the International Association of Seismology and Physics of the Earth's Interior (IASPEI), which came into being at the Brussels Assembly in 1951 as the successor of the former International Association of Seismology (IAS). As a consequence the European Seismological Commission (ESC) was set up.

The 1967 IUGG meeting in Zurich was her last IUGG meeting, and she presented a paper (Lehmann, 1968). I was participating in the same meeting, and I can confirm the statement in Bolt (1997, p 291), that Lehmann was extremely sensitive to noise. She had reserved an expensive hotel room downtown Zurich, but found out that the hotel could not guarantee that it was a quiet room. When she heard that my hotel room was cheaper and quieter she offered me the expensive hotel room in exchange of mine, and would pay the price difference. However very early on the first morning I was woken up by loud streetcar noise. So I left the hotel in exchange of a cheap, quiet camping site, and both Inge Lehmann and the Danish Geodetic Institute saved money. One of the documents in the Inge Lehmann archive shows that in Cambridge 1966 E.R. Lapwood promised to give Inge Lehmann a quiet room in Emanuel College. During 1928-1929 the Danish Geodetic
Institute (Geodætisk Institut) was carrying out the Seismological Service in Denmark. This service was done by National Survey and Cadastre - Denmark during 1989-2004 and from then it has been carried out by Geological Survey of Denmark and Greenland (GEUS).

Inge Lehmann was succeeded 1953 at the Danish Geodetic Institute by Henry Jensen (1915-1974 ), an experienced geodesist and, after 1953 seismologist. She exchanged letters with him, on the subject of the loan of books, journals and seismograms. She also attended the European Seismological Commission General Assembly in Copenhagen, 1966, organized by him. Henry Jensen became the first professor of Geophysics at University of Copenhagen in 1965. Jørgen Hjelme, succeeded him at the Danish Geodetic Institute, later National Survey and Cadastre - Denmark until 1995, where he was succeeded by Søren Gregersen, now at GEUS.

A small seismic array station, named Inge Lehmann station, situated $77^{\circ} 55^{\prime} \mathrm{N}, 39^{\circ} 14^{\prime}$ $\mathrm{W}, 2400 \mathrm{~m}$ above sea level, on the Greenland Ice Cap started in June 1966 as a Danish American cooperative project (Lenton, 1968). The project showed that the station is very sensitive to small events, and a project in 1967 (project Blue Trek) showed that the low noise and good signal found at the Lehmann station is also found on a large portion of the Ice Cap, while Camp century near the edge is quite noisy. The station was run until September 1967.

Lehmann's name will continue to be honoured in the geophysical world. In 1996 the American Geophysical Union established the Inge Lehmann Medal. It is given for 'outstanding contributions towards the understanding of the structure, composition and/or dynamics of the Earth's mantle and core'. It is awarded in odd-numbered years.

Lehmann donated her entire estate and fortune to a fund administered by the Danish Academy of Sciences and Letters. It offers a travel award each year alternatively to a psychologist and a geophysicist. Those awards started while Lehmann was still living, and the first chairman of the awards committee of the Lehmann Foundation, Elvin Kejlsø told me, that she was happy to know that the people who 
were awarded the Lehmann award could use it as an important qualification in their curriculum vitae. The current chairman is Søren Gregersen.

Inge Lehmann remained involved with the scientific community throughout her long life. She participated in a reception held at the Danish Geodetic Institute on her 100th birthday in 1988, and a large number of geophysicists from both sides of the Atlantic participated. Some of them had participated in a workshop on «Causes and Effects of Earthquakes at Passive Margins and in Areas of Postglacial Rebound on both sides of the North Atlantic» held in Vordingborg, Denmark, May 9-13, 1988 (Gregersen and Basham, 1989). V. Keilis-Borok and C. Kisslinger were there because IUGG bureau had a meeting in Copenhagen the following days. The Danish Geophysical Society (Claus Hammer) convened the reception, and Elvin Kejls $\varnothing$, V. Keilis-Borok, Carl Kisslinger and Søren Gregersen gave talks. She really enjoyed that the proceedings were tape recorded, enabling her to listen to them repeatedly.

A humorous mistake is documented in the children's book about Inge Lehmann (Jensen and Pedersen, 1996, p 57). It shows a letter from the hospital dated January 25, 1989 addressed to Inge Lehmann's parents, long since deceased. Judging from the two digits, 88 allotted to the year of Lehmann's birth in the personal number, the hospital assumed that she was almost 1 year old instead of almost 101. The same book shows several pictures of Inge Lehmann. One shows her mother, grandmother and great-grandmother, and on page 57 it credits Michael Bernth Pedersen with helping Lehmann write her last paper on seismology. Bernth Pedersen helped with everyday problems, since he lived nearby, while I helped her when she needed help from a seismologist, looking up references, or typing up manuscripts. Michael helped her keep up her fighting spirit until her death. Many of Inge Lehmann's non-seismological books and one of the flags from the Inge Lehmann station are now in Michael's possession.

In his obituary of Inge Lehmann Nils Groes writes:

«One day at the hospital, Inge told us that all day she had been thinking about her own life and she was content. It had been a long and rich life full of victories and good memories.».

When Inge Lehmann received the award from the Seismological Society of America (Oliver, 1978) Jack Oliver at Cornell University mentions her charming summer cottage in Holte that so many seismologists have visited. I was invited there as late as summer 1990, and was impressed by the way she answered the phone from someone that was surprised to find her there. She pretended that going out to one's summerhouse when the weather is good is the obvious thing to do when you are only 102 years of age ( Of course I am in the summerhouse», she said).

Lehmann's many awards are documented in table II. A more detailed biography was given by Bolt and Hjortenberg (1994) and by Bolt (1997).

\section{The Inner Core Discovery}

The way Inge Lehmann discovered the inner core was by observing unexpected large amplitudes in the shadow zone (Lehmann, 1936). Lehmann's last paper (Lehmann, 1987) has a fig. 4b, also published in Lehmann (1931). The text written on the top of that figure is in German, in translation it reads: Frankenfurter travel time curves, made by B. Gutenberg 1928. The figure contains a continuation of the $\mathrm{P}^{\prime}$ curve extending from $142^{\circ}$ to $100^{\circ}$ and tagged «gebeugte Wellen?» (Bent waves with a question mark). The question mark shows that in 1928 Gutenberg was not sure that the waves were diffracted, but he did not get the idea that these waves came from an inner core. Lehmann (1936) presented the idea, and reflected and refracted rays from the inner core in Lehmann's simple earth model explained the waves. Gutenberg readily accepted the idea of an inner core (Gutenberg and Richter, 1938, p. 364), while Jeffreys was slower to do so (Jeffreys, 1939, p. 554). The wording of Gutenberg and Richter was that they accepted Lehmann's hypothesis

«that the observations of P' are not due to diffraction in a normal manner through the core. How- 
Table II. Inge Lehmann's many awards.

\begin{tabular}{|c|c|}
\hline Year(s) & Awards to Inge Lehmann \\
\hline 1936-1948 & Member of the Executive Committee of the International Seismological Association. \\
\hline 1938 & Tagea Brandt Award. \\
\hline $\begin{array}{l}1951-1954 ; \\
1957-1960\end{array}$ & $\begin{array}{l}\text { Member of the Executive Committee of the International Association of Seismology and } \\
\text { Physics of the Earth's Interior (IASPEI). }\end{array}$ \\
\hline 1957 & Associate Royal Astronomical Society, London. \\
\hline 1959 & Honorary Fellow Royal Society, Edinburgh. \\
\hline 1960 & The Harry Oscar Wood Award in Seismology. \\
\hline $1963-1967$ & $\begin{array}{l}\text { Vice President of the Executive Committee of the International Association of Seismology } \\
\text { and Physics of the Earth's Interior. }\end{array}$ \\
\hline 1964 & $\begin{array}{l}\text { Doctor of Science (Sc.D.) h.c. Colombia University in the city of New York. } \\
\text { Deutsche Geophysikalische Gesellschaft, Emil-Wiechert Medal. }\end{array}$ \\
\hline 1965 & Kgl. Danske Videnskabernes Selskab (Royal Danish Academy of Sciences and Letters) Gold Medal \\
\hline 1967 & Tagea Brandt Award. \\
\hline 1968 & Doctor of Philosophy (Dr. phil.) h.c. University of Copenhagen. \\
\hline 1971 & $\begin{array}{l}\text { American Geophysical Union, Bowie Medal given for outstanding contributions to fundamental } \\
\text { geophysics and unselfish cooperation in research. }\end{array}$ \\
\hline 1973 & Honorary membership of European Geophysical Society. \\
\hline 1977 & Medal of the Seismological Society of America. \\
\hline
\end{tabular}

ever, the velocity distribution required to account for these observations differs greatly from the hypothetical model used in her paper».

This great difference is not surprising; she was not trying to estimate the real velocities but presented a simple earth model with constant velocity in each shell of the model, so that the time distance curve could be calculated by simple trigonometry and paths were straight lines. The wording of Jeffreys (1939) was «It seems therefore that diffraction must be abandoned as an explanation of PKP at distances less than 142 degrees». Additional confirmation of the inner core was given by Engdahl et al. (1970) by using the Large Aperture Seismic Array (LASA).

Inge Lehmann discovered the inner core, but it is not correct to say that she discovered the solid inner core, her model does not consider the question about whether the inner core is solid or fluid, that was done by others much later (e.g. Birch, 1940; Bullen, 1946; Bolt, 1987 and Cao et al., 2005). Hence she discovered the inner core, that later proved to be solid.

Simon (1993) discusses her personal memoir of Inge Lehmann:

«I had heard long before her arrival at Lamont, that she was the seismologist who had proved the existence of the inner core of the Earth».

A short but good version of the story of the inner core discovery is given by Oliver (1978):

«Her best-known paper, succinctly entitled P' demonstrated that this phase is not the result of dif- 
fraction as was held at that time, but was a clear indication of an inner core of higher velocity, thus revealing to mankind for the first time this major feature of the earth.».

Schweitzer (2003a, p. 19) gives another short but good version of the same story:

«Both Gutenberg and Jeffreys overlooked the existence of an inner core, which was discovered by the Danish seismologist Inge Lehmann (1888-1993; Emmerich and Schweitzer, 1988; Bolt, 1997; Kertz, 2002) in 1936 (Lehmann, 1936; 1987).».

Brush (1980, p. 706) notes that it is the last name of Inge Lehmann that is associated with the discovery of the inner core, but few people outside the geophysical/seismological community seem to realize that one of the most important discoveries about the structure of the earth was made by a woman.

Bischoff (2004) notes that in her studies of the 1929 Buller, New Zealand earthquake, Inge Lehmann had found that the stations Swerdlowsk and Irkutsk had substantial amplitudes although they were in the shadow zone. Bischoff also claims that Jeffreys four years before the publication in 1936 did not show interest in Lehmann's conclusions about a possible inner core. This lack of interest in 1932 on the part of Jeffreys was displayed in a poster at the ESC Potsdam 2004 General Assembly. The poster showed how the idea of a discontinuity surface within the core was proposed in the last lines of her letter to Jeffreys dated May 31, 1932 (Hjortenberg and Larsen, 2004), it is also shown here.

The first page of the letter is shown in fig. 2, second page is shown in fig. 3 , in the last lines of the second page she proposes the idea of a discontinuity surface within the core. At the discontinuity surface the velocity increase with depth. She wrote that there is hardly anything to disprove such a surface in present observational data.

In a letter from Jeffreys dated June 1 (figs. 4 and 5), he remarks;

«Macelwane is a bit casual about the core. I should have thought that a good Jesuit would have jumped at the discovery of hell, but he reacts all wrong.».

In Jeffreys' June 4, 1932 letter he does not comment the proposal.

The letter from Jeffreys dated 1932 June 1 was not shown in Potsdam 2004, it was somehow overlooked in the Lehmann archive in 2004 when documents were selected for the poster, and it is shown here in fig. 4 and fig. 5 . Therefore Bischoff were led to believe that Jeffreys were uninterested in the inner core. It is surprising that it is dated already the day after Lehmann's letter. It is interesting to note that in Lehmann's letter shown in figs. 2 and 3 attention is given to the mantle discontinuity as well as to the inner core discontinuity, but she doesnot use the word mantle.

\section{The Lehmann discontinuities}

Birch (1971) gave a speech when Inge Lehmann was awarded the Bowie medal by the American Geophysical Union. He said that her 1936 paper added a new discontinuity to the seismic structure of the earth, the Lehmann discontinuity, which divided the core into inner and outer parts.

Don Anderson $(1979,1981)$ use the title Lehmann discontinuity for a discontinuity in the mantle at $190-250 \mathrm{~km}$ and this use continues. On February 26-28, 2004, a symposium organised by Hans Thybo and entitled «Seismic Heterogeneity in the Earth's Mantle: ThermoPetrological and Tectonic Implications», was held at the Royal Danish Academy of Sciences and Letters, Copenhagen with Don Anderson as key speaker. At the symposium it was decided that the use of the expression «Lehmann discontinuity» also for a mantle discontinuity is OK. During the symposium it was clear that each time the Lehmann discontinuity was mentioned the mantle discontinuity was meant.

Karato (1992) and references therein give additional examples of the use of the expression Lehmann discontinuity for an upper mantle discontinuity. Karato proposes the Lehmann discontinuity $(\sim 200 \mathrm{~km})$ to result from a change in anisotropy structure with depth. 


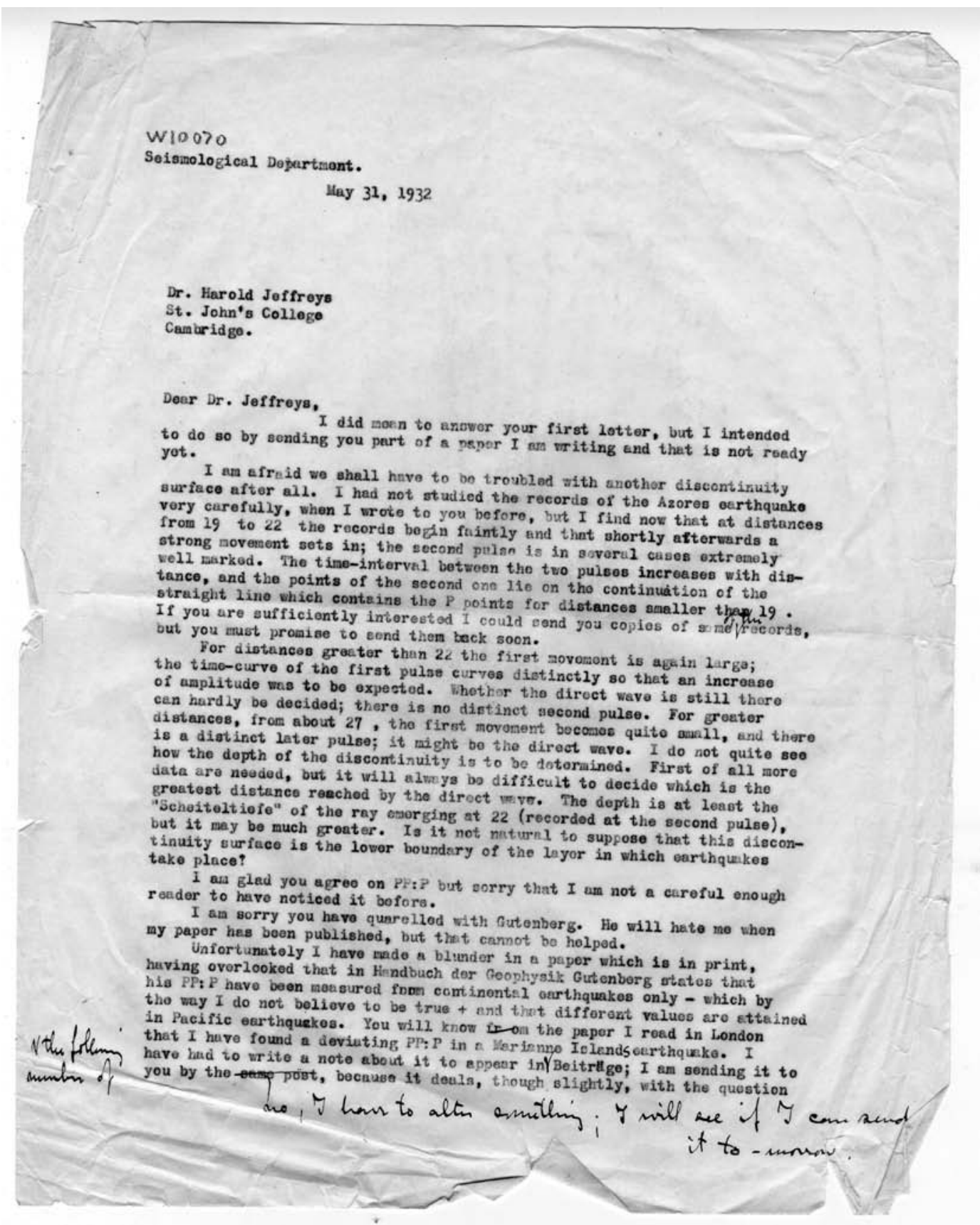

Fig. 2. First page of Inge Lehmann's May 31, 1932 letter. She offers to send records of the Azores earthquake that shows the discontinuity in the upper layers using the records at distances from 19 to 22 degrees. 


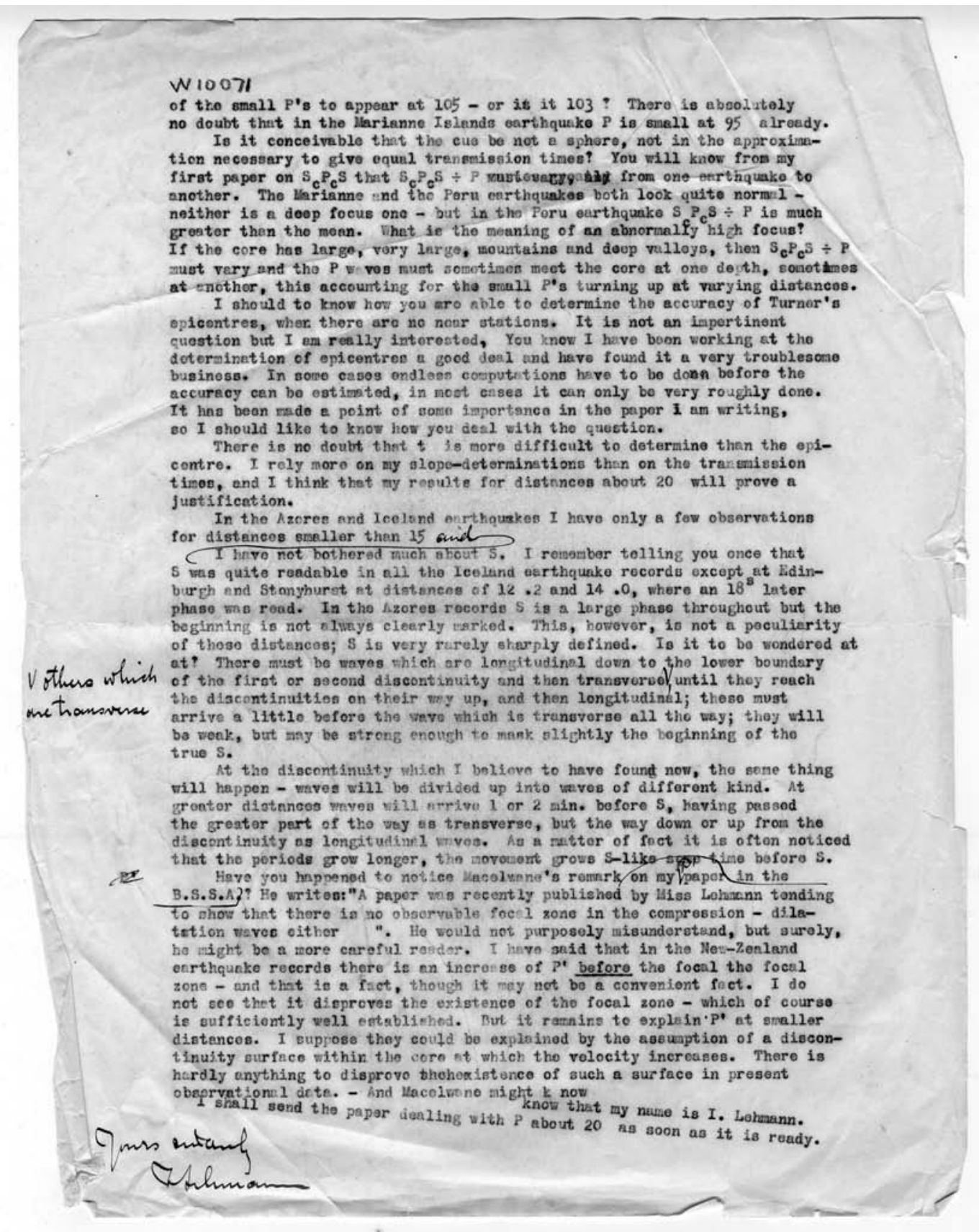

Fig. 3. Second page of Inge Lehmann's May 31, 1932 letter. Only the last 15 lines are about the inner core. They deal with the «increase of P' before the focal zone». «I suppose they could be explained by a discontinuity surface within the core at which the velocity increases». In the paragraphs before the last 15 lines one or two discontinuities in the upper layers are discussed. 


\section{Post-retirement research}

In 1951 Maurice Ewing, who had discovered the phase Lg together with Frank Press (Press and Ewing, 1952), visited Copenhagen (Lehmann, 1978), and he invited Inge Lehmann to come to Lamont (now Lamont-Doherty) to assist in the study of Lg. In 1952 she made her first visit to the United States, and when Inge Lehmann retired in 1953; 5 years before the mandatory retirement, she felt free to carry out seismological studies at home and abroad. While at the Lamont-Doherty Earth Observatory in 1953 Lehmann published studies of three European earthquakes (Lehmann, 1953a), and explained the behaviour of $P$ and $S$ waves on the assumption of a low-velocity layer at some depth below the Mohorovicic discontinuity. Gutenberg (1948) made the assumption that in California small amplitudes in $\mathrm{P}$ and $\mathrm{S}$, and a certain delay can be explained by the presence of a low velocity layer at a depth of about $80 \mathrm{~km}$ Lehmann (1953a, p. 483) remarked that in Eastern North America there is no comparable deep shadow for $\mathrm{S}$ as there is in Europe.

In subsequent years Lehmann continued her upper mantle investigations (Lehmann, 1955). Lehmann (1957) report some results of the $\mathrm{Lg}$ studies started in 1951, and she found that the deep earthquakes she investigated did not produce Lg waves, but the shallow ones did. She concludes that a closer study of the phase $\mathrm{Lg}$ should yield interesting and important results. This prediction became true near Denmark when Kenneth et al. (1985) showed a barrier for Lg waves in the North Sea.

Lehmann and Ewing (1960) deals with Lg waves as recorded in Copenhagen. The paper is bound in two volumes, one with text and one with diagrams. Figure 1 to 31 of these diagrams show copies of seismograms, often with $\mathrm{Lg}$ waves coming from south or east of Copenhagen, but figure 17 shows the seismograms from both Scoresbysund and Copenhagen of an Arctic earthquake also discussed by Oliver et al. (1955). Figure 32 is a map of all the earthquakes considered in the 1960 paper.

Inge Lehmann published the Jeffreys and the Lehmann model for the $\mathrm{P}$ velocities in the upper 800 kilometers of the mantle (Lehmann, 1959, p. 390). The Lehmann model differs from Jeffreys' below the Mohorovicic discontinuity, where Jeffreys has $7.75 \mathrm{~km} / \mathrm{s}$ and Lehmann has $8.0 \mathrm{~km} / \mathrm{s}$ and Lehmann's velocities have a discontinuity at 220 kilometres depth. Her later studies use data from nuclear explosions (Lehmann, 1962; 1964) and interpret a phase observed by Romney (1959) as a P wave refracted in a discontinuity at a depth of $215 \mathrm{~km}$. Her interpretation (Lehmann, 1967) of low velocity layers and a $220 \mathrm{~km}$ discontinuity was used in making earth models, e.g. the PREM model (Dziewonski and Anderson, 1981). The authors state that their decision to locate discontinuities at 220, 400 and $670 \mathrm{~km}$ was based on results from many other studies. Lehmann (1970) concludes that the nature of the deep discontinuity in $\mathrm{P}$ velocity varies and it may not be present everywhere.

\section{The work materials and epistolary archive}

Inge Lehmann's collection of work materials is large, and it contains books, papers, documents, reprints, card files and seismograms (e.g. from the Heligoland explosions 1947). One interesting example is a handwritten document from a seminar she gave on the 10th of May 1954 in Pasadena. It is about the upper mantle of the earth, its different structure in Europe, California and NE America.

There is also an envelope with papers about the first Danish seismologist, E.G. Harboe (1845-1919), stating that he retired from the military in 1897 .

The Inge Lehmann epistolary archive contains letters from many countries, including Italy, Austria, Australia, Russia, Germany, Denmark, France, UK, USA and Canada. The Inge Lehmann archive altogether contains many thousands of documents that Lehmann stored in her home. They were scanned and catalogued on 2005-2006 by SGA by Storia Geofisica Ambiente (Bologna), producing more than 5000 files, each containing one or more scanned pages. It is important that each page in the archive can now be uniquely identified by the filename and the number in the file, and the directory names and structure may be regarded as a catalogue. 
St John's College

Cambridge

England.

W10068

1932 une 1.

Dear M1ss Lehmann,

Meny thanks for your very informat1ve letter. I'm sorry about the new discontinulty; is if we hadn't enough trouble already No, please don't send me the records; I am snowed under with my present work, and trying hard to get all the revised epicentres ready for Comrle to compute new $\Delta$ 's. Then I ląll have to do all the residuals over again.

I have just read your G.B. paper. The eplcentre of the 1925 Nov. 13 earthquake should be $12^{0} .5 \mathrm{~N}, 124^{\circ} .7 \mathrm{E} . ; 0^{0} .5$ south of the I.S.S. position. The principle I act on 1 s that if the tables are systematic right we won't get/depertures from them in any case; but if we try to find epicentres and To's statistically, and there $1 \mathrm{~s}$ anything

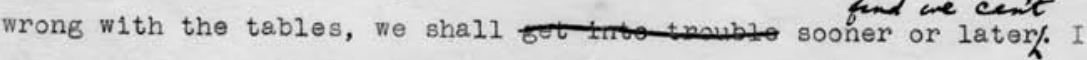
have found some slight troubles, but nothing enough to make me sure that it is not simply due to accidental errors of observation. Th1s earthquake happens to be rather a nice one. Taking out the P residuals they fall into four groups. Japan and China to the notth, mean $=+15 \mathrm{~s}$. ; Australla and New Zealand about azmmuth $150^{\circ},=+4.6 \mathrm{~s}$; Ind1a to $\mathrm{W}$. , +11 s.; Eurtefe, distant in azimuth $315^{\circ}$. If $\mathrm{x}$ is the displacement to $S$ and $y$ to $E$, we have $\& 4$ equations for $x, y$, and $T_{0}$. I left out India and got from the others $x=0.55 ; y=00.05 ;$ correction to $T_{0}=\$ 8.4 \mathrm{~s}$. India is actually a bit north of $w$. and of about 1.0 , which $1 \mathrm{~s}$ good enough. Actuelly four good groups ( $1 \mathrm{t}$ is quite unusual for the South Pac1fic or the Indian stations to agree among themselves, but on this occasion they dol. Then we have only three equations, just enough, and can judge

Fig. 4. First page of Jeffreys' 1932 June 1 letter. «Thank you for your very informative letter. I'm sorry about the new discontinuity». " No please don't send me the records; I am snowed under with my present work». It appears that Jeffreys is not interested in the new discontinuity in the mantle. 


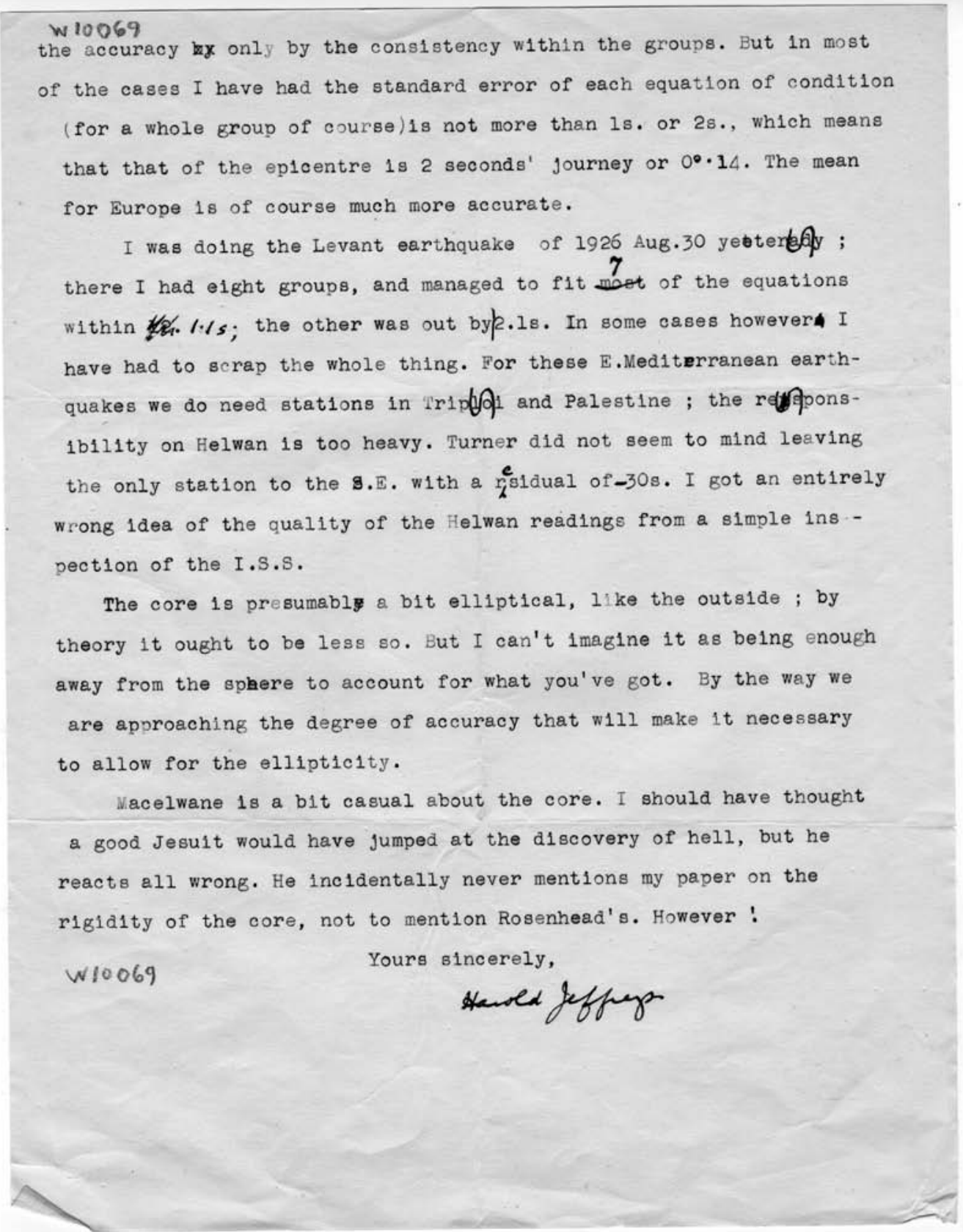

Fig. 5. Second page of Jeffreys' 1932 June 1 letter. The main subject is epicentre determinations, by the group method, but in the last paragraph the inner core discontinuity surface is discussed: «Macelwane is a bit casual about the core. I should have thought a good Jesuit would have jumped at the discovery of hell, but he reacts all wrong». 


\subsection{More on the Brussels, 1951 assembly, start of European Seismological Commission (ESC)}

In a two page machine typed document Inge Lehmann describes in Danish the assembly of the International Seismological Association in Brussels 1951. The following two paragraphs are a translation of some of that document:

«In Brussels 1951 Inge Lehmann participated in the meeting of the Commission on the Physics of the Earth's Interior (COPEI) that led to putting COPEI's work under the International Seismological Association (later called IASPEI).

Inge Lehmann also took part in the meeting where cooperation between European seismologists was discussed. They found that the best solution would be that the Association sets up a European Commission. Later 5 delegates requested such a commission, and it got 13 members from 13 countries.

The Commission (European Seismological Commission, ESC) held one meeting on which Inge Lehmann was elected president, but she refused. Then Wilhelm Hiller was elected president of ESC with Pietro Caloi as secretary. Beno Gutenberg was elected president of the Association with Pietro Caloi and Harold Jeffreys as vice-presidents.».

\subsection{Epistolary archive, Sir Harold Jeffreys (UK) and others}

\section{In 1971, Lehmann (1971) recalled:}

«I was the only Danish seismologist for 25 years. I began to work on travel times and I was fortunate in that Harold Jeffreys, who at that time was doing his important work on travel time tables could use some of my research. For several years we had quite a correspondence, this was, of course a great encouragement to me.».

\section{In 1994, Lady Jeffreys (1994) wrote:}

«It was not until my marriage to Harold Jeffreys in 1940 that I knew of the importance of Inge Lehmann's work in observational seismology and for the next five years it was not possible for them to communicate with each other $\left({ }^{1}\right)$. He must have had letters from her in the 1930s but I regret that these have disappeared.».
The Inge Lehmann archive contains a big envelope marked, in translation:

«Correspondence with Harold Jeffreys before the war, about time curves, somewhat disordered, first letter from December 19, 1930».

They may be difficult to put in order, since Jeffreys often wrote the day and month, but not the year, on his letters. I believe that in most cases the year can be deduced from the exact placement of the letter and the content of the letter. Less than a quarter of the about 150 letters in the envelope are dated drafts of letters from Lehmann to Jeffreys, so there may have been more letters and it is a pity that the letters received by Jeffreys have disappeared.

The correspondence between Inge Lehmann and Sir Harold Jeffreys about the inner core of the earth was discussed in Chapter 3. Another example of correspondence topics is the letter from Jeffreys August 23, it was answered by Inge Lehmann August 30, 1934. His letter contained the proof of his manuscript to Nature, No. 280 on the State of the Earth's Central core. It refutes the assertion by the seismologist L. Bastings from New Zealand that he observed S waves through the earth core. Jeffreys' article said that:

«The lack of rigidity in the core does not rest wholly on the past failure to identify $S$ waves through it. [...]. If Bastings' interpretation is correct, it will be necessary to suppose that the core is elasticoviscous, behaving as solid for stresses with periods of a few seconds but as a liquid for a period of 12 hours.».

The letter from Inge Lehmann confirms her view that Jeffreys is right in believing that $\mathrm{L}$. Bastings has read PPS for $\mathrm{S}_{1}$ ', the latter being the hypotetical $\mathrm{S}$ wave through the core. The manuscript proof referred back to Bastings (1934), to Jeffreys $(1929 ; 1926)$ and to Lehmann (1930; 1931). Later on Lehmann (1950, p. 196) comments further on Bastings' interpretation:

«Amongst the phases he determined were those of the transverse waves transmitted through the core. There are as we have seen, many phases in the records of some of the stations, so many, indeed, that 
W10072

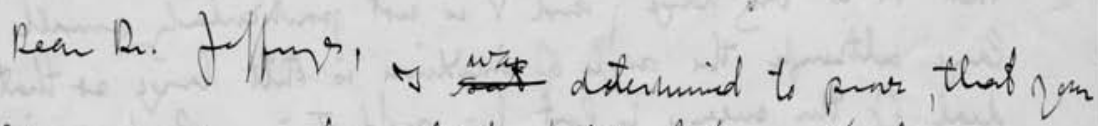

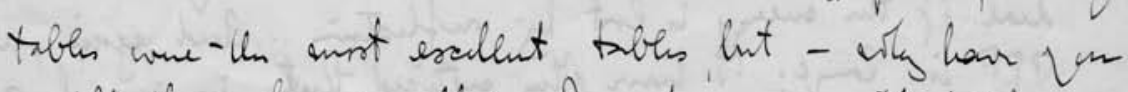

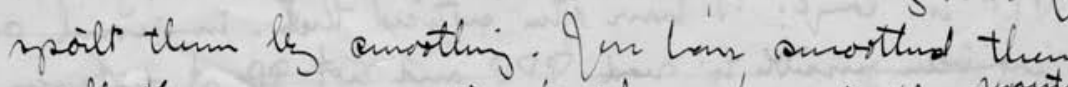

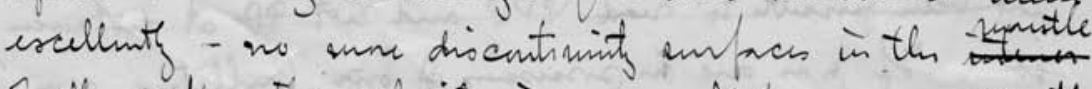
of the eaith. The velveity in cuases firat mone rapidy then aniy with arth.

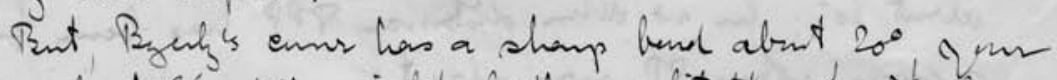

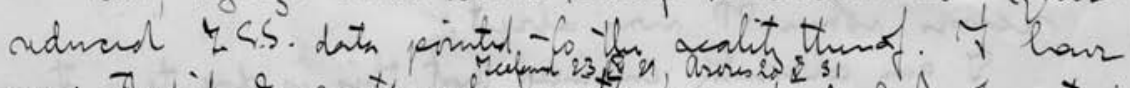

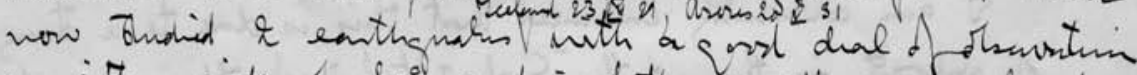
on intrm sider of Lol and in both cases the cunve bends

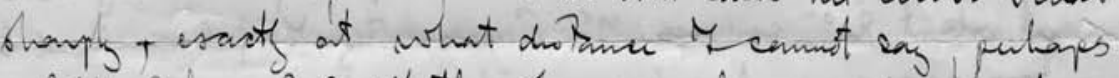

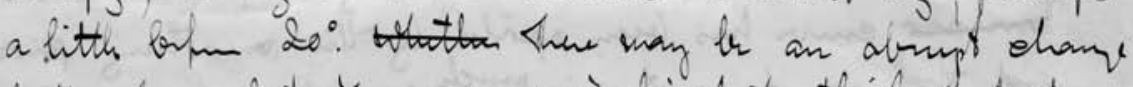
of the bupe het 5 an wne inclined to thim that it

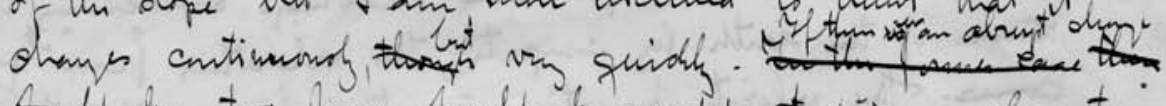

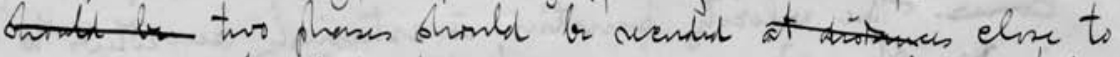

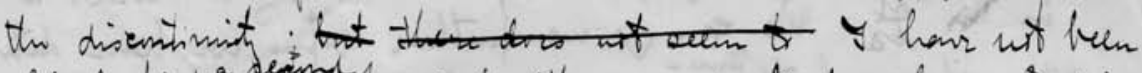

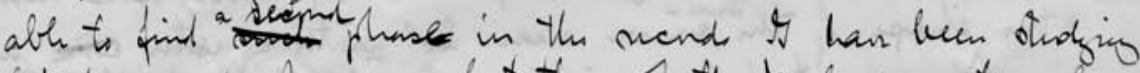

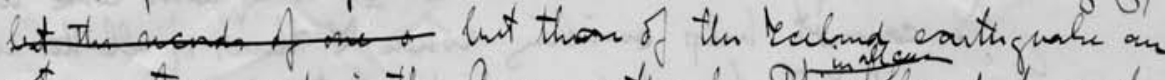

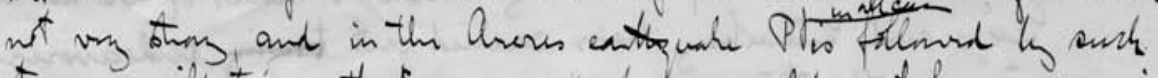
oting ascillation that a second phase cunde not be iz enspi. cuons.

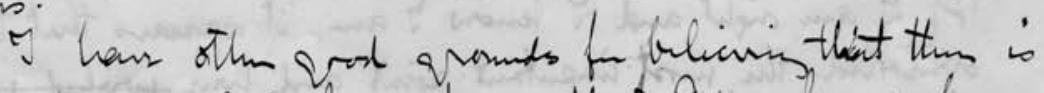

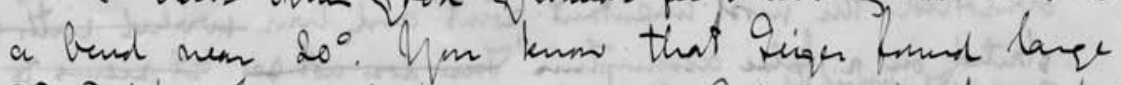

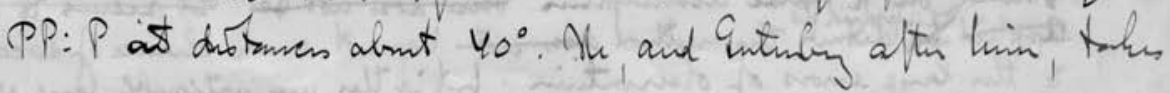

Fig. 6. First page of Inge Lehmann's May 6, 1932 letter to Harold Jeffreys. 
In granter that thy anc due to rmall $P_{5}$. As a mattre a

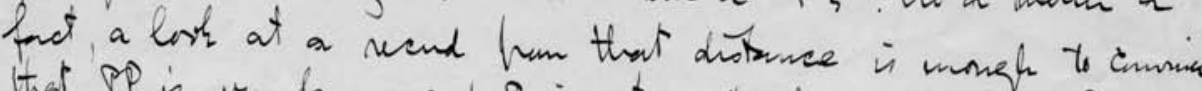
that PP is vy lave; and $P$ is not pantionluch emall. PP is

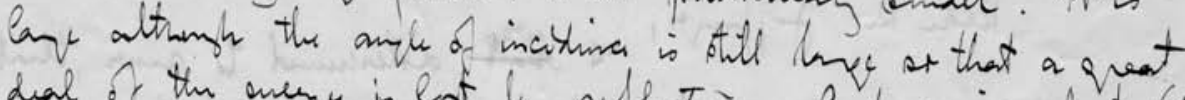

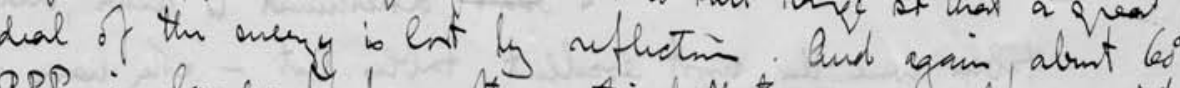

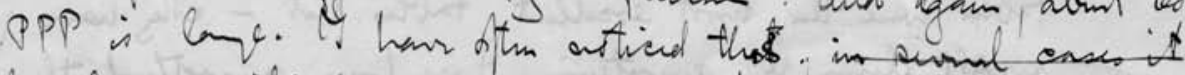

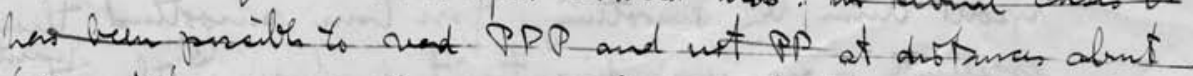

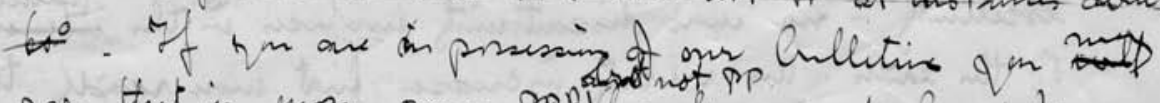
see that in unay emses MPPithas buen and fundistanees alent $60^{\circ}$. In wo Ithen distences PPP has bem fund in newin when PP wers alsent.

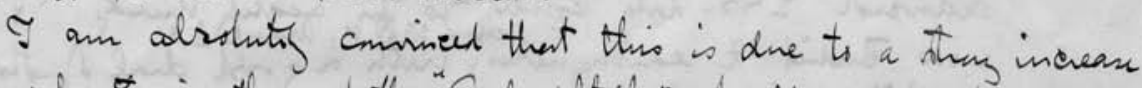
of vilrit the at the "Scheitiltief" of the ray which uneres

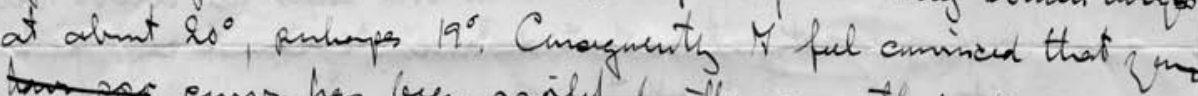
trooness enus has been opilul $y$-Un conothing proveso

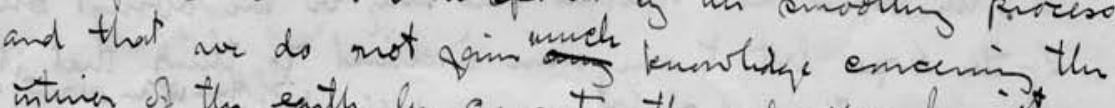

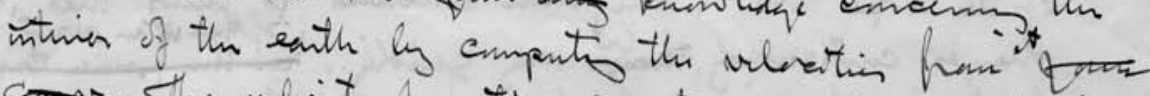
cons. The veliet onstion, is extiemb ansitis to changs

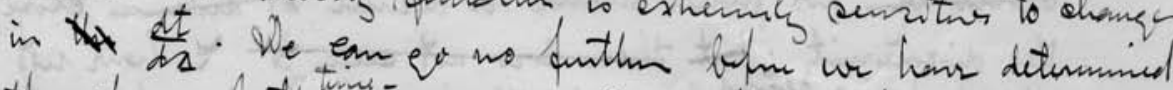

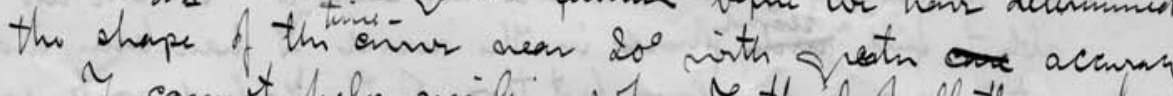
- camit help ening when $f$ thing ff all the wats

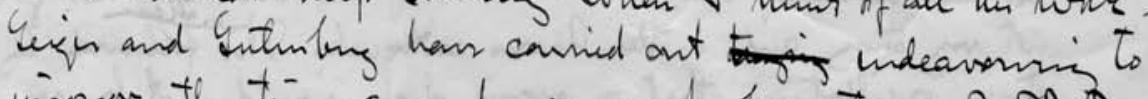
impar the tims-eme by eneans of obsenstum of PP: P. If I an sight and I know I am, it assears that they has

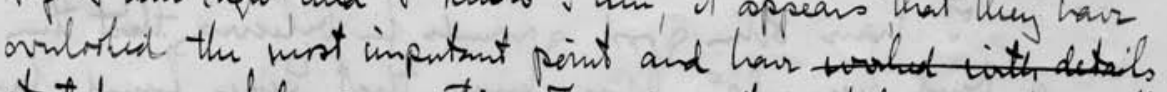

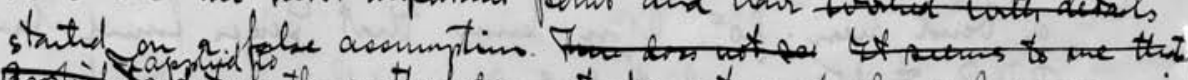

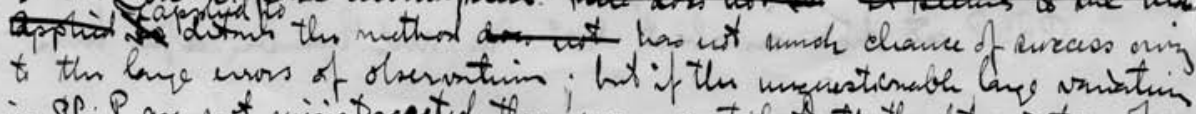

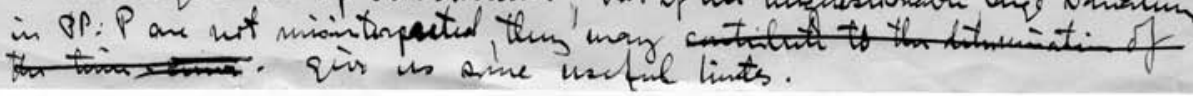

Fig. 7. Second page of Inge Lehmann's May 6, 1932 letter to Harold Jeffreys. This paper was also shown in Potsdam 2004, and one of the words is German, Scheiteltiefe, the depth reached by the deepest ray. 
it will be possible to pick out phases to fit almost any time-curve, but a proof of the existence of the corresponding phase is not obtained in this way. It is not obtained unless there is a concentration of points close to the curve.». Lehmann (1953b)

further discuss Bastings' publications during the time span 1933-1937.

Many other observations can be derived from the correspondence with Jeffreys:

On May 6, 1932 Lehmann writes:

«I was determined to prove that your tables were the most excellent tables, but - why have you spoilt them by smoothing. You have smoothed them excellently - no more discontinuity surfaces in the mantle of the earth. The velocity increases first more rapidly then slowly with depth. But Byerly's $\left({ }^{2}\right)$ curve has a sharp bend about $20^{\circ}$, your reduced ISS $\left(^{3}\right)$ data pointed to the reality thereof. I have now studied two earthquakes Iceland, Azores with a good deal of observations on either side of $20^{\circ} . »$ (The full text of the letter is shown in figs. 6 and 7).

On November 18, 1932 she sends a letter to Jeffreys about her time curve:

«I feel quite sure about the bend about $20^{\circ}$, but that is exactly the sort of thing which is not exhibited by the statistical method.».

On December 14, 1932 she writes again:

«I am glad to hear that - at last - you believe in the bend about $20^{\circ} . »$.

On March 29, 1936 she writes about amplitudes at distances $12^{\circ}$ to $15^{\circ}$.

«If you had seen so many records from these distances as I have seen, I am sure you would not doubt that amplitudes are abnormally small.».

Such observations are examples of the historic and scientific value of letters in earth science (Ferrari, 2002), (Ferrari, 2003). It shows e.g. that the inner core was discussed 4 years before Lehmann (1936). We are fortunate that Lehmann kept drafts or carbon copies of the outgoing letters and not only the letters she received.

Letters from Harold Jeffreys from after the war are filed in different places in the archive.
There is also correspondence with Pietro Caloi, for instance, in connection with the publication of the work of the Vatican meeting (Lehmann, 1952), and correspondence with a lot of other seismologists, e.g. with B. Gutenberg, V. Conrad, P.V. Willmore, S. Müller. M. Båth. F. Press, M. Ewing, J. Oliver, E. Peterschmitt, and J.H. Hodgson.

\subsection{Niels Bohr archive}

The Niels Bohr archive has made copies of 9 letters from the correspondence between Lehmann and Bohr and 3 letters about Inge Lehmann. Seven letters of those 9, and one season's greeting were written by Inge Lehmann at Newnham College, Cambridge in 1911. They deal with invitations for tea, and the necessity of a chaperone, which must have surprised Inge Lehmann after Hanna Adler's school. She sent a message of congratulation to Niels Bohr at the Carlsberg mansion (now Carlsberg Academy) in honour of his 60 years birthday on October 7 , 1945. A letter dated October 11, 1947 thanks Mrs Bohr for a beautiful box left at the death of Hanna Adler, and adds that a copy of Inge Lehmann's paper on Hanna Adler is enclosed. It also recalls Inge Lehmann's visits to her when she had to miss her family who were in Sweden.In the letter Inge Lehmann adds that it was always a pleasure to visit Miss Adler.

In a letter January 14, 1962 from Harold Jeffreys to Niels Bohr, he wonders whether Inge Lehmann has ever received any honour in her own country. In a letter July 11, 1962 from Niels Bohr to Niels Erik Nørlund (Lehmann's former director) he suggests the award of the Gold Medal of the Danish Academy of Scienses and Letters. In a letter to Niels Bohr dated August 22, 1962 Niels Erik Nørlund confirms that he will propose that when the Academy meets again. The medal was awarded in 1965.

\subsection{Additional items to Bibliography}

A bibliography with Inge Lehmann's publications on microfiche with 59 references is in- 
cluded with Bolt (1997). Information about additional references has been found in the Lehmann archive. That information is given in the present publication as Lehmann (1948b; 1948c; 1965; 1971; 1978).

A paper with 32 pages and 9 plates entitled «The seismological stations København and Scoresbysund» was published by the Geodetic Institute in 1930. It is undoubtly written by Inge Lehmann, but author's name is not given in the publication.

\section{Conclusions}

This paper deals with Inge Lehmann's achievements and the Inge Lehmann archive. The safeguarding of the Inge Lehmann archive was done by SGA (Storia Geofisica Ambiente in Bologna) by scanning and cataloguing the documents 2005-2006.

The files obtained can help getting a better understanding of Inge Lehmann's publications and of the historical development that she was part of. The paper also shows how she presented the idea of an inner core to Jeffreys 4 years before 1936, and Jeffreys reply.

\section{Acknowledgements}

Thanks to Graziano Ferrari for inviting me to the meeting on Ischia 2003, and thanks to Søren Gregersen, Niels Groes, Kristian Hvidtfelt, Tine Larsen, Tyge Lehmann, Louise Palmer, Michael Bernth Pedersen, Felicity Pors, Torben Risbo, Peter Voss and Bente Winstrøm for valuable comments.

\section{Notes}

(1) Because of World War II and the German occupation of Denmark.

${ }^{(2)}$ American seismologist.

${ }^{3}$ ) International Seismological Summary, an annual publication with epicenter determinations and readings of phases. It was replaced by International Seismological Centre (ISC) bulletins in 1964. Lehmann played a key role in the initiation of ISC.

\section{REFERENCES}

AdLER-SAMFundet (1959): Hanna Adler og hendes skole, udgivet i 100-året for Hanna Adlers fodsel den $28 \mathrm{Maj}$ 1959, with a preface by NiELs BoHR, (GEC Gads Forlag, København), p. 183 (in Danish).

ANDERSON, D.L. (1979): The deep structure of the continents, J. Geophys. Res., 84, 7555.

ANDERSON, D.L. (1981): Discontinuities in the mantle (abstract), EOS Trans. AGU, 62, 1073

BANG, T. (1988): Niels Erik Nørlund in memoriam, Acta Matematica, 161 (1-2), 11-22.

BASTINGS, L. (1934): Shear Waves through the Earth's Core, Nature, 134, 216.

BIRCH, F. (1940): The alpha-gamma transformation of iron at high pressures, and the problem of the earth's magnetism, Am. J. Sci., 238, 192.

BIRCH, F. (1971): William Bowie Medal to Inge Lehmann, EOS, 52, 537-538.

Bischoff, J. (2004): Das Geheimnis der P-Wellen (in German), GEOkompakt, 1, 60-61.

BoLT, B.A. (1987): 50 years of studies on the inner core, EOS, 68, 80.

BoLT, B.A. (1997): Inge Lehmann. Biographical Memoirs of Fellows of the Royal Society of London, 43, 285-301 (also on internet).

Bolt, B.A. and E. HJortenberg (1994): Inge Lehmann (1888-1993), Bull. Seis. Soc. Amer., 84 (1), 229-233.

BuLLEN, K.E. (1953): The rigidity of the Earth's inner core, Ann. Geofis., 6, 1.

BRush, S.G. (1980): Discovery of the Earth' core, Am. J. Phys., 48 (9), 705-724.

BRush, S.G. (1985): Women in physical sciences, The Physics Teacher, 11-19.

CaO, A., B. Romanovich and N. Takeuchi (2005): An observation of PKJKP: Inferences on Inner Core Shear Properties, Science, (published online 14 April, sciencexpress 2005 0: 11091341).

DZIEWONSKI, A.M. and D.L. ANDERSON (1981): Preliminary reference Earth model, Phys. Earth. Planet. Int., 25, 297-356.

EMMERICH, H. and J. SCHWEITZER (1988): Inge Lehmann die Entdeckerin des inneren Erdkerns, Deutsche Geophysikalische Gesellschaft e. V., Mitteilungen , 2, 5-6, (in German).

ENGDAHL, E.R., E.A. FlinN, and C.F. Romney (1970): Seismic waves reflected from the Earth's inner core, $\mathrm{Na}$ ture, 228, 852 . 
FERRARI, G. (2002): Letters in the earth sciences: their historic value and present-day scientific relevance, Annals of Geophysics, 45 (5), 703-707.

FERRARI, G., (2003): Census, filing and elaboration of scientific letters in earth sciences, Nuncius, 17 (1), 307320.

Gregersen, S. and P.W. Basham (1989): Earthquakes at North-Atlantic Passive Margins:Neotectonics and Postglacial Rebound, Proceedings of NATO Advanced Research Workshop in Vordingborg, May 9-13. 1988, NATO ASI series, Series C, 2-66, (Kluwer Academic Publishers, Dordrect, Boston and London), 716.

Gregersen, S, J. HJelme and E. HJortenBerg (1998): Earthquakes in Denmark, Bull. Geol. Soc. Denmark, 44, 115-127.

GuTENBERG, B. (1914): Über Erdbebenwellen, VIIA. Nachr. Ges. Wiss. Göttingen Math. Physik. Kl, 166., 125, (in German).

GutENBERG, B. and C.F. Richter (1938): P' and the Earth's core, Mon. Not. Roy. Soc. Geoph. Suppl, 4 (5), 363-372.

GUTENBERG, B. (1948): On the layer of relatively low wave velocity at depth of about 80 kilometers, Bull. Seismol. Soc. Amer., 38, 121-148.

HANSEn, T. (1962): Det lykkelige Arabien: En dansk ekspedition 1761-67, (2nd edition, Gyldendal, København), (in Danish)

Hansen, T. (1964): Arabia Felix: The Danish expedition of 1761-1767, (1st edition, Collins, London).

HJortenberg, E. and T.B. LARSEN (2004): The Scientific Correspondence between Inge Lehmann and Harold Jeffreys, ESC XXIX Abstract Volume, 76.

JefFreys, H. (1926): Mon. Not. Roy. Soc. Geoph. Suppl., 1, 371-383.

JeFFREYs, H. (1929): The Earth, its Origin, History and Physical Constitution, (2nd edition, e University Press, Cambridge), 238.

JefFreys, H.(1939): The times of the core waves, Mon. Not. Roy. Soc., Geoph. Suppl., 4, 548-561.

JEFFREYS, LADY B. SwIRLES (1994): Inge Lehmann; REMINISCENSES, Quarterly J. Roy. Astr. Society, 35 (2), 231.

Jensen, S.S. and H.B. Pedersen (1996): Inge Lehmann kvinden og jordskalvene, (Gyldendal, København ), p. 64 (in Danish).

Karato, S. (1992): On the Lehmann discontinuity, Geophysical Research Letters, 19 (22), 2255-2258.

Kenneth, B., S. Gregersen, S.M. MykKeltveit and R. NEWMARK (1985): Mapping of crustal heterogeneity in the North Sea basin via the propagation of $\mathrm{Lg}_{\mathrm{g}}$-waves, Geophysical Journal of the Royal Astronomical Society, 83, 299-306.

KERTZ, W. (2002): Biographische Lexicon zur Geschichte der Geophysik, edited by K.H. GLASSMEIER and R. KerTz, (Braunschweigische Wissenschaftliche Gesellschaft, Braunschweig), p. 384 (in German).

Kousholt, B. (2004), Inge Lehmann og jordens kerne, (Polyteknisk Forlag), p. 90, (in Danish).

LehmanN, I. (1930): P' as read from the records of the earthquake of June 16th 1929, Gerl. Beitr. Geophys., 26, 402-412.

LehmanN, I. (1931): Die Bedeutung der Europäischen Stationsgruppe für die Bestimmung von seismischen Laufzeitkurven, (in German), Verhandl. Fünften Tagung Balt. Geod Commission, 192-212, Helsinki.
Lehmann, I. (1936): P', Publications du Bureau Central Seismologique International, Série A, Travaux Scientifique, 14, 87-115.

LeHMANN, I. (1948a): On two explosions in Danish waters in the autumn of 1946, Geofisica Pura e Applicata, 12, 3-19.

LEHMANN, I. (1948b): Jordskælv som kilde til øget viden om jordens indre, (in Danish), Salmonsens Leksikontidsskrift, 8, 808-812.

LeHMANN, I. (1948c): Seismic recording in Europe, 1948, Association Séismol. Comptes Rendus, Séances Conférences Strasbourg 4-8 Juillet 1947, 79-83.

LeHMANN, I. (1950): On the reading of earthquake diagrams and the interpretation of phases, Publ. Bur. Cent. Seism. Int. A, 17, 193-204.

LEHMANN, I. (1952): On the microseismic movement recorded in Greenland and its relation to atmospheric disturbances. Ponteficiae Acad. Scient. Scripta Varia, 23, 73-109.

LEHMANN, I. (1953a): P and S at distances smaller than $25^{\circ}$, Transactions of American Geophysical Union, 34 (3), 477-483.

LeHMANN, I. (1953b): On the shadow of the Earth's core, Bull. Seismol. Soc. Amer., 43, 291-306.

Lehmann, I. (1955): The times of P and S in Northeastern America, Annali di Geofisica, 8 (4), 351-370.

LeHMANN, I. (1956): Danske jordskælv, Meddelelser fra Dansk Geol. Forening, 13 (2), 88-103, (in Danish).

LEHMANN, I. (1957): On Lg as read on Northamerican records, Annali di Geofisica, 10 (1-2), 1-21.

LEHMANN, I. (1959): Velocities of longitudinal waves in the upper part of the earth's mantle, Ann. Géophys., 15, 93118, Publ. Dom. Obs. Ottawa, 19 (10), 381-406.

LeHMANN, I. and M. EwING (1960): On short-period surface waves as recorded in Copenhagen, Geodactisk Instituts Skrifter 3. Rakke, Memoires de l'institut Géodésique de Danemark Troisième Série, 34, pp. 19 + 32 figures, separately bound, and respectively marked Text and Diagrams.

LEHMANN, I. (1962): The travel time of the longitudinal waves of the Logan and Blanca atomic explosions and their velocities in the upper mantle, Bull. Seismol. Soc. Amer., 52 (3), 519-528.

LeHMANN, I. (1964): On the travel times of P as determined from nuclear explosions, Bull. Seismol. Soc. Bull., 54 (1) $123-139$

LEHMANN, I. (1965): Errata (to) On the travel times of P as determined from nuclear explosions, Bull. Seismol. Soc. Amer., 55 (1), 201.

LeHMANN, I. (1967): Low-velocity layers, in The Earth's Mantle, edited by T.F. GASKELL, (Academic, New York), 41-62.

LEHMANN, I. (1968): Discontinuous velocity changes in the mantle as derived from seismic travel times and amplitudes, Bur Centr. Seism. Int. A, 24, 167-174.

Lehmann, I. (1970): The 400-km Discontinuity, Geophys. J. R. astr. Soc., 21, 359-372.

Lehmann, I. (1971): William Bowie Medal to Inge Lehmann, Acceptance and response by Inge Lehmann, EOS, 52, 538 .

LehmanN, I. (1978), Response, Third Award of the Seismological Society of America (in 1977), Bull. Seismol. Soc. Amer., 68 (4), 1210.

Lehmann, I. (1987): Seismology in the days of old, EOS, 68, $33-35$ 
Lenton, R. A. (1968): Greenland Ice Cap Noise Studies, Project Blue Ice, Arctic Institute of North America, Washington, D. C., Research Paper No. 47.

Oliver, J., M. Ewing and F. Press (1955): Crustal studies of the Arctic region from the Lg phase, Bull. Geol. Soc. America, 66, 1063-1074.

Oliver, J. (1978), Citation, Third Award of the Seismological Society of America (in 1977), Bull. Seismol. Soc. Amer., 68 (4), 1209.

Press, F. and M. EwING (1952), Two slow surface waves across North America, Bull. Seismol. Soc. Amer., 42, 219-228.

RomNeY, C.F. (1959): Amplitudes of seismic body waves from underground nuclear explosions, J. Geophys. Res, 65, 1039-1051.
Schweitzer, J. (2003a), Chapter 79, Part A, Early German contributions to modern seismology, in IASPEI - International Handbook of Earthquake and Engineering Seismology, Part B, edited by W.H.K. Lee, H. Kanamori, P.C. Jennings, and C. KissLINGER, (Academic Press), ISBN 0-12-440658-0. Schweitzer, J. (2003b), Chapter 79, Part D: Prof. Dr. Beno Gutenberg The bibliography in IASPEI International Handbook of Earthquake and Engineering Seismology, Part B, edited by W.H.K. LeE, H. Kanamori, P.C. JeNNINGS, and C. KISSLINGER, (Academic Press), ISBN 012-440658-0.

SimON, R. (1993), A personal memoir of Inge Lehmann (1888-1993), EOS, 74, 511-512. 